\title{
EWSR1/PATZ1 Fusion Protein Short Isoform
}

National Cancer Institute

\section{Source}

National Cancer Institute. EWSR1/PATZ1 Fusion Protein Short Isoform. NCI Thesaurus.

Code C99243.

A fusion protein (609 aa, $65 \mathrm{kDa}$ ) encoded by the EWSR1/PATZ1 fusion gene short isoform. This protein is comprised of the transactivation domain of the RNA-binding protein EWS fused to the C-terminus of POZ-, AT hook-, and zinc finger-containing protein 1 containing two $\mathrm{C} 2 \mathrm{H} 2$ zinc-finger DNA binding domains. 